\title{
Effects of seagrass Thalassia testudinum on sediment redox
}

\author{
S. Enríquez ${ }^{1}$, N. Marbà ${ }^{2, *}$, C. M. Duarte ${ }^{2}$, B. I. van Tussenbroek ${ }^{1}$, G. Reyes-Zavala ${ }^{1}$ \\ ${ }^{1}$ Unidad Académica de Puerto Morelos, Instituto de Ciencias del Mar y Limnología, Universidad Nacional Autónoma \\ de México, Apto. Postal 1152, 77500 Cancún, Quintana Roo, Mexico \\ ${ }^{2}$ Grup d'Oceanografia Interdisciplinar, Institut Mediterrani d'Estudis Avançats (CSIC-UIB), C/Miquel Marquès 21, \\ 07190 Esporles, Illes Balears, Spain
}

\begin{abstract}
The redox conditions were compared in vegetated versus unvegetated sediments across a range of contrasting Thalassia testudinum (sometimes mixed with Syringodium filiforme) meadows at Puerto Morelos Mexico reef lagoon. Moreover, the role of seagrass photosynthetic activity in affecting the redox conditions was tested in one of the meadows by experimentally reducing seagrass photosynthesis through shading. The seagrass rhizosphere extended 26 to $40 \mathrm{~cm}$ into the sediment, and accounted for 23 to $504 \mathrm{~g} \mathrm{DW} \mathrm{m}^{-2}$ of root material, mostly contributed by T. testudinum. T. testudinum placed $50 \%$ (i.e. centroidal depth) and $95 \%$ of its root biomass within $12.6 \pm 0.58$ and $54.4 \pm$ $2.53 \mathrm{~cm}$ of the sediment surface, respectively; while $S$. filiforme placed 50 and $95 \%$ of its root biomass within $8.0 \pm 0.87$ and $34.7 \pm 3.8 \mathrm{~cm}$ of the sediment surface, respectively. Vegetated sediments presented $50 \%$ of positive redox potential anomaly (i.e. redox potential in vegetated sediments - redox potential in adjacent bare sediments), remarkably similar ( $t$-test, $p>0.5)$ to depths to the centroidal depth of the seagrass roots in the sediments. The shading experiment conducted in situ for $5 \mathrm{~d}$ demonstrated that the positive redox anomaly found at depth in vegetated sediments was derived from seagrass photosynthetic activity. The sediments around seagrass rhizosphere in the shaded plots were progressively reduced to reach an average decline of the redox conditions by about $45 \mathrm{mV}$ by Day 5 . The results presented show that seagrasses contribute to modify sediment redox conditions around their rhizosphere.
\end{abstract}

KEY WORDS: Thalassia testudinum · Syringodium filiforme - Rhizosphere · Redox conditions · Mexican Caribbean

Resale or republication not permitted without written consent of the publisher

\section{INTRODUCTION}

Seagrass beds, which rank among the most productive communities in the biosphere (Duarte \& Chiscano 1999) maintain a number of ecosystem functions, such as carbon storage, food-web support, and oxygenation of the water column (e.g. Duarte \& Cebrián 1996, Gattuso et al.1998). Seagrasses live in the interface between the water column and the sediments, and extend metabolically active surfaces (leaves and roots) in both of these environments. Whereas the effects of seagrass metabolism on water-column properties have been extensively documented, the possible effects in

${ }^{*}$ Corresponding author. E-mail: ieanmb@clust.uib.es the sediments are still poorly investigated (Hemminga 1998). There is, however, solid evidence that seagrasses release oxygen through their roots (Pedersen et al. 1998, Connell et al. 1999, Terrados et al. 1999), which may affect the redox conditions of the sediment around the rhizosphere. This role of seagrass roots will, if confirmed, influence the metabolic pathways of the associated sediment bacteria, thereby influencing sediment biogeochemical processes.

Here, we examine the hypothesised effect of seagrass roots on sediment redox conditions across a range of seagrass meadows growing in the Mexican Caribbean. We first compare redox conditions in vegetated versus unvegetated sediments across a range of contrasting meadows within a reef lagoon, and then we test the role 
of seagrass photosynthetic activity in affecting the redox conditions by experimentally reducing seagrass photosynthesis in situ through shading.

\section{MATERIAL AND METHODS}

We examined the effect of seagrass vegetation on sediment redox conditions in 7 seagrass meadows of a Mexican reef lagoon (Puerto Morelos, Quintana Roo, Yucatan) in October 1999. Of the 4 meadows examined which grow along the coastline, 2 are exposed to heavy wave action and 2 are situated in the coastal fringe somewhat deeper. Another 2 meadows are in the middle part of the lagoon, and 1 other meadow is close to the coral reef (Fig. 1). Thalassia testudinum, the most abundant Caribbean seagrass species, was present in all of the selected meadows, which differed in aboveground biomass and species composition (Table 1).

At each site, we harvested 5 replicated 20 by $20 \mathrm{~cm}^{2}$ quadrats for aboveground plant biomass, and collected between 3 and 4 sediment cores to estimate root biomass and determine sediment redox conditions. In addition, we collected 2 to 3 cores from unvegetated sediments adjacent to the vegetated ones. The PVC cores had an internal diameter of $7.3 \mathrm{~cm}$, were $50 \mathrm{~cm}$ long, and had 2 opposite vertical lines of $1.3 \mathrm{~cm}$ diameter holes, spaced every $4 \mathrm{~cm}$ and placed $2 \mathrm{~cm}$ out of phase on each line. The holes were sealed with waterproof adhesive tape prior to sampling. Sediment redox potential was measured immediately after sampling with a Crison redox electrode coupled to a portable $\mathrm{pH}$ meter (Crison model 507), calibrated with a redox standard solution at $25^{\circ} \mathrm{C}$ (Crison $468 \mathrm{mv}$ ). Sediment

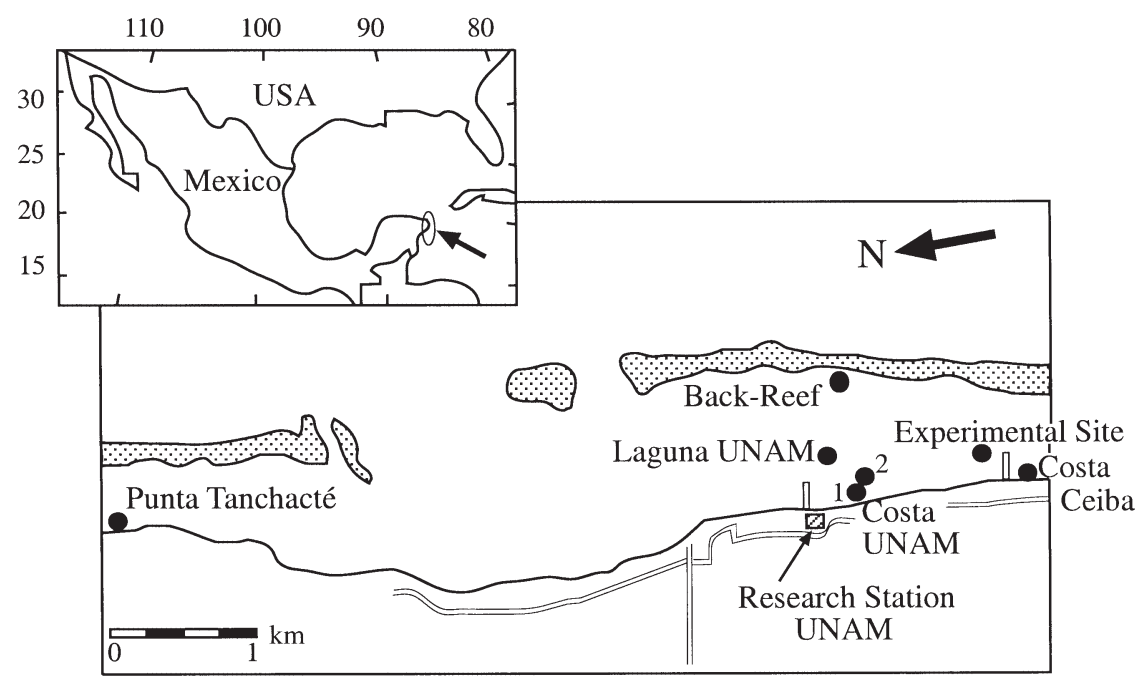

Fig. 1. Map of the reef lagoon of Puerto Morelos indicating sampling locations redox potential values were obtained by carefully removing the waterproof adhesive tape covering each of the holes in the core wall, and inserting the electrode into the sediment. We repeated this procedure for each hole along the core, starting from the sediment-water interface down to the deepest sediment sampled. We alternately punched the sediment through the holes of each opposite and out-of-phase vertical line, obtaining redox measurements every $2 \mathrm{~cm}$ along sediment depth.

We chose to measure redox potential as an indicator of the general biogeochemical conditions in the sediment, while acknowledging the limitations of this approach (e.g. Stumm \& Morgan 1996, Schüring et al. 2000). Platinum electrodes, as those used here, are not inert, forming Pt-oxides in oxic environments, which can be prevented by regularly cleaning and polishing them. Some redox couples $\left(\mathrm{NO}_{3}{ }^{-}-\mathrm{NO}_{2}{ }^{-}-\mathrm{NH}_{4}{ }^{+} ; \mathrm{CH}_{4}-\mathrm{CO}_{2}\right)$ are not electro-active at the surface of the Pt electrode and, therefore, were missed. Yet, the nitrate concentrations in sediments and waters in the Caribbean areas investigated were very low $\left(0.62\right.$ to $2.49 \mu \mathrm{M} \mathrm{NO}_{3}{ }^{-}-\mathrm{NO}_{2}{ }^{-}$in pore water; 0.07 to $1.99 \mu \mathrm{M} \mathrm{NO}_{3}{ }^{-}-\mathrm{NO}_{2}{ }^{-}$in water column, Pantoja-Reyes unpubl. data), indicating the error of Pt electrode estimates of sediment redox potential to be small. Similarly, an important $\mathrm{CH}_{4}-\mathrm{CO}_{2}$ component was unlikely, given the Eh values measured, to be present. Hence, the range of redox values and the oligotrophic conditions in the system investigated suggest that measurements by Pt electrodes provide an adequate approximation of redox potentials in this environment and that measurement bias is kept to a minimum. However, the redox potential measured with Pt electrodes reflects a mixture of several reactions, preventing a quantitative inference on the actual processes occurring.

Therefore, sediment redox potential in this study provided an indication of the gross geochemical conditions in the sedimentary environment, without providing insight into the actual processes taking place.

The plant samples and sediment cores were transported to the laboratory. We determined the species composition of the aboveground plant material, splitting them into 4 main groups: Thalassia testudinum, Syringodium filiforme, rhizophytic macroalgae, and non-rhizophytic macroalgae. The sorted samples were weighed after drying for $24 \mathrm{~h}$ at $60^{\circ} \mathrm{C}$. Sediment cores were cut into $2 \mathrm{~cm}$ thick slices, and sieved to separate seagrass belowground material from sediment and debris. Alive rhi- 
Table 1. Average ( $\pm \mathrm{SE}$ ) seagrass and macroalgal biomass $\left(\mathrm{g} \mathrm{DW} \mathrm{m} \mathrm{m}^{-2}\right.$ ) and organic content in the top $10 \mathrm{~cm}$ of sediment in the meadows studied. Plant biomass was estimated from 5 samples. The number of observations (n) of sediment organic content is given within parentheses

\begin{tabular}{|c|c|c|c|c|c|}
\hline Site & Species & Aboveground & Rhizomes & Roots & Sediment organic content (\%) \\
\hline Costa UNAM1 & $\begin{array}{l}\text { Thalassia testudinum } \\
\text { Syringodium filiforme } \\
\text { Non-rhizophytic algae } \\
\text { Rhizophytic algae }\end{array}$ & $\begin{aligned} 25.7 & \pm 4.5 \\
0.6 & \pm 0.2 \\
158.0 & \pm 101.0 \\
20.5 & \pm 5.7\end{aligned}$ & $\begin{aligned} 289.0 & \pm 27.5 \\
11.8 & \pm 4.2\end{aligned}$ & $\begin{aligned} 162.0 & \pm 20.0 \\
18.3 & \pm 6.4\end{aligned}$ & $1.47(5)$ \\
\hline Experimental site & $\begin{array}{l}\text { Thalassia testudinum } \\
\text { Syringodium filiforme } \\
\text { Non-rhizophytic algae } \\
\text { Rhizophytic algae }\end{array}$ & $\begin{array}{r}30.6 \pm 5.3 \\
2.1 \pm 1.6 \\
9.0 \pm 6.0 \\
24.5 \pm 7.0\end{array}$ & $\begin{array}{r}269.0 \pm 75.0 \\
23.9 \pm 18.5 \\
237.0 \pm 70.0\end{array}$ & $\begin{array}{r}274.9 \pm 88.8 \\
35.9 \pm 21.4\end{array}$ & $2.63(1)$ \\
\hline Arrecife & $\begin{array}{l}\text { Thalassia testudinum } \\
\text { Syringodium filiforme } \\
\text { Non-rhizophytic algae } \\
\text { Rhizophytic algae }\end{array}$ & $\begin{aligned} 19.9 & \pm 2.2 \\
5.7 & \pm 2.6 \\
17.2 & \pm 19.3 \\
15.4 & \pm 3.3\end{aligned}$ & $22.0 \pm 2.2$ & $\begin{aligned} 147.3 & \pm 24.8 \\
23.4 & \pm 5.1\end{aligned}$ & $2.38(2)$ \\
\hline Pta. Tanchacté & $\begin{array}{l}\text { Thalassia testudinum } \\
\text { Syringodium filiforme } \\
\text { Non-rhizophytic algae } \\
\text { Rhizophytic algae }\end{array}$ & $\begin{array}{r}163.6 \pm 6.5 \\
1.4 \pm 1.5 \\
0 \\
0\end{array}$ & $372.0 \pm 155.0$ & $106.0 \pm 40.0$ & $2.98(1)$ \\
\hline Costa UNAM 2 & $\begin{array}{l}\text { Thalassia testudinum } \\
\text { Syringodium filiforme } \\
\text { Non-rhizophytic algae } \\
\text { Rhizophytic algae }\end{array}$ & $\begin{aligned} 11.5 & \pm 6.9 \\
87.6 & \pm 22.4 \\
104.6 & \pm 46.2 \\
66.5 & \pm 29.9\end{aligned}$ & $\begin{array}{l}125.0 \pm 12.0 \\
195.0 \pm 41.0\end{array}$ & $\begin{array}{l}28.5 \pm 7.8 \\
95.3 \pm 20.6\end{array}$ & $4.59(1)$ \\
\hline Laguna UNAM & $\begin{array}{l}\text { Thalassia testudinum } \\
\text { Syringodium filiforme } \\
\text { Non-rhizophytic algae } \\
\text { Rhizophytic algae }\end{array}$ & $\begin{array}{l}29.8 \pm 11.7 \\
11.4 \pm 2.9 \\
51.4 \pm 26.7 \\
15.9 \pm 10.4\end{array}$ & $\begin{array}{r}149.0 \pm 44.2 \\
33.0 \pm 12.1\end{array}$ & $\begin{array}{c}159.0 \pm 36.5 \\
32.8 \pm 9.4\end{array}$ & $2.82(2)$ \\
\hline Ceiba orilla & $\begin{array}{l}\text { Thalassia testudinum } \\
\text { Syringodium filiforme } \\
\text { Halodule wrightii } \\
\text { Non-rhizophytic algae } \\
\text { Rhizophytic algae }\end{array}$ & $\begin{array}{c}112.4 \pm 6.6 \\
15.9 \pm 8.4 \\
0.3 \\
0 \\
7.0 \pm 4.7\end{array}$ & $\begin{array}{c}765.0 \pm 312.0 \\
29.9 \pm 12.0\end{array}$ & $\begin{array}{r}425.0 \pm 85.0 \\
79.5 \pm 33.4\end{array}$ & $1.79(4)$ \\
\hline
\end{tabular}

zomes and roots were sorted by species, dried at $60^{\circ} \mathrm{C}$ for $24 \mathrm{~h}$, and weighted. A sediment subsample of vegetated sediment was also dried at $60^{\circ} \mathrm{C}$ for $24 \mathrm{~h}$, and burned at $400^{\circ} \mathrm{C}$ for $2 \mathrm{~h}$. These measurements provided estimates of aboveground biomass, depth distribution of rhizosphere biomass, and sediment organic matter content.

We selected a middle lagoon meadow (3.3 m deep) to perform a shading experiment to test the link between seagrass photosynthetic activity and sediment redox conditions (Experimental Site, Fig. 1). We reduced the irradiance on three $2 \mathrm{~m}^{2}$ seagrass plots by $73 \%$ of the ambient level, by placing 3 cages covered with a neutral (i.e. with a homogeneous light absorption spectrum along the PAR range) density net. Another three $2 \mathrm{~m}^{2}$ plots with uncovered cages were used as controls. The light reduction in the shaded plots was determined in situ, $5 \mathrm{~d}$ after the start of the experiment, by measuring simultaneously scalar irradiance at $5 \mathrm{~cm}$ above the sediment in the middle of 1 shaded and 1 control plot, with two $4 \pi$ sensors coupled to a Li-Cor data logger (LI-1400) over $4 \mathrm{~h}$. Sediment redox condi- tions and the photosynthetic activity of Thalassia testudinum, the dominant seagrass species, were measured at the beginning of the experiment, and 2,5, and $10 \mathrm{~d}$ after the experiment was initiated. Between Days 5 and 10, a strong frontal system passed by, leading to disturbance derived from abrupt changes in water temperature (decrement of $3^{\circ} \mathrm{C}$ ), and sediment resuspension, which reduced underwater light by $45 \%$. Sampling of the plots was conducted at the time of peak irradiance (i.e. between 12:00 and 14:00 h). At each sampling, we collected 1 PVC sediment core from each plot and measured the vertical profile of sediment redox potential as described above.

We directly followed the response of the photosynthetic activity of Thalassia testudinum to shading by estimating Electron Transport Rate of photosystem II $\left(E T R, \mu m o l \mathrm{e}^{-} \mathrm{m}^{-2} \mathrm{~s}^{-1}\right)$, which is the apparent relative rate of electron transport using a diving PAM fluorometer (Diving-PAM Walz, Germany). We did so measuring in situ the steady-state fluorescence $\left(F_{V} / F m^{\prime}\right)$ of the second youngest leaf of the shoot yield at $5 \mathrm{~cm}$ above the sediment, on 5 replicates per plot. We also deter- 
mined leaf light availability at $5 \mathrm{~cm}$ above the sediment using a $2 \mathrm{~mm}$ diameter cosine corrected light sensor (Miniature Fiberoptics Diving-F1) connected to the Quantum sensor of the Diving-PAM housing. This sensor was previously calibrated against a LI-192SA cosine corrected light sensor attached to a data-logger (Li-Cor Inc., USA). Water temperature was recorded simultaneously using a water temperature sensor built in Diving-PAM device. ETR was estimated according to the equation proposed by Genty et al. (1989),

$$
E T R=F_{\mathrm{v}} / F_{\mathrm{m}}{ }^{\prime} \times P A R \times \text { Absorptance } \times 0.5
$$

where $F_{\mathrm{v}} / F_{\mathrm{m}}$ ' is the steady state fluorescence yield, $P A R$ is the instantaneous photosynthetic active irradiance, Absorptance is the fraction of incident light absorbed by the leaf, and 0.5 is a constant derived from the fact that there are 2 coupled photosystems simultaneously absorbing light. Absorptance was determined for each sampling day by measuring spectrophotometrically leaf absorptance on 6 shaded and 6 control second leaves using a dual-beam spectrophotometer SLM-AMINCO (DW-2C, UV-VIS) equipped with 2 opal-glass units (Shibbata 1959).

Redox measurements were corrected to obtain Eh values relative to the standard hydrogen electrode (APHA 1992). We calculated the redox potential anomaly in each site as the difference between the average redox potential at similar depths into the sediment in vegetated and bare sediments. Similarly, the redox potential anomaly in the experimental plots was estimated as the difference between the average redox potential at similar depths into the sediment in control and shaded plots on Days 2, 5, and 10. We summarized the depth distribution of seagrass root biomass and redox potential anomaly using the model $Y=1-\beta^{d}$ (Gale \& Grigal 1987), where $Y$ is the fractional cumulative (i.e. fraction between 0 and 1) root biomass and redox potential anomaly, respectively, from the sediment surface to depth $d(\mathrm{~cm})$, and $\beta$ is the fitted extinction coefficient (Jackson et al. 1996). The equation was fitted using non-parametric regression (Wilkinson 1989). The centroidal depth of root biomass and redox potential anomaly is calculated using the model, as the sediment depth comprising 50 and $95 \%$ of the root biomass or positive redox potential anomaly.

\section{RESULTS}

The meadows surveyed ranged widely in macrophyte biomass (Table 1), with 2 of the meadows dominated by Thalassia testudinum and the rest of them comprising a mixed seagrass ( $T$. testudinum and Syringodium filiforme) and algal community (Table 1). The communities were all growing over carbonate sediments (mostly coral rubble and Halimeda-derived carbonate, Duarte et al. 1995) with relatively low organic content $(2.1 \%$ DW, Table 1$)$. The seagrass rhizosphere extended 26 to $40 \mathrm{~cm}$ into the sediment (Fig. 2), and jointly contributed 23 to $504 \mathrm{~g} \mathrm{DW} \mathrm{m}^{-2}$ of root material, representing 14 to $46 \%$ of the total seagrass biomass, mostly contributed by $T$. testudinum (Table 1). 50 and $95 \%$ of the root biomass was comprised within the sediment layer 10 to 15 and $>40 \mathrm{~cm}$ deep, respectively (Table 2), but this depth differed significantly ( $t$-test, $\mathrm{p}<0.01$ ) between seagrass spe-
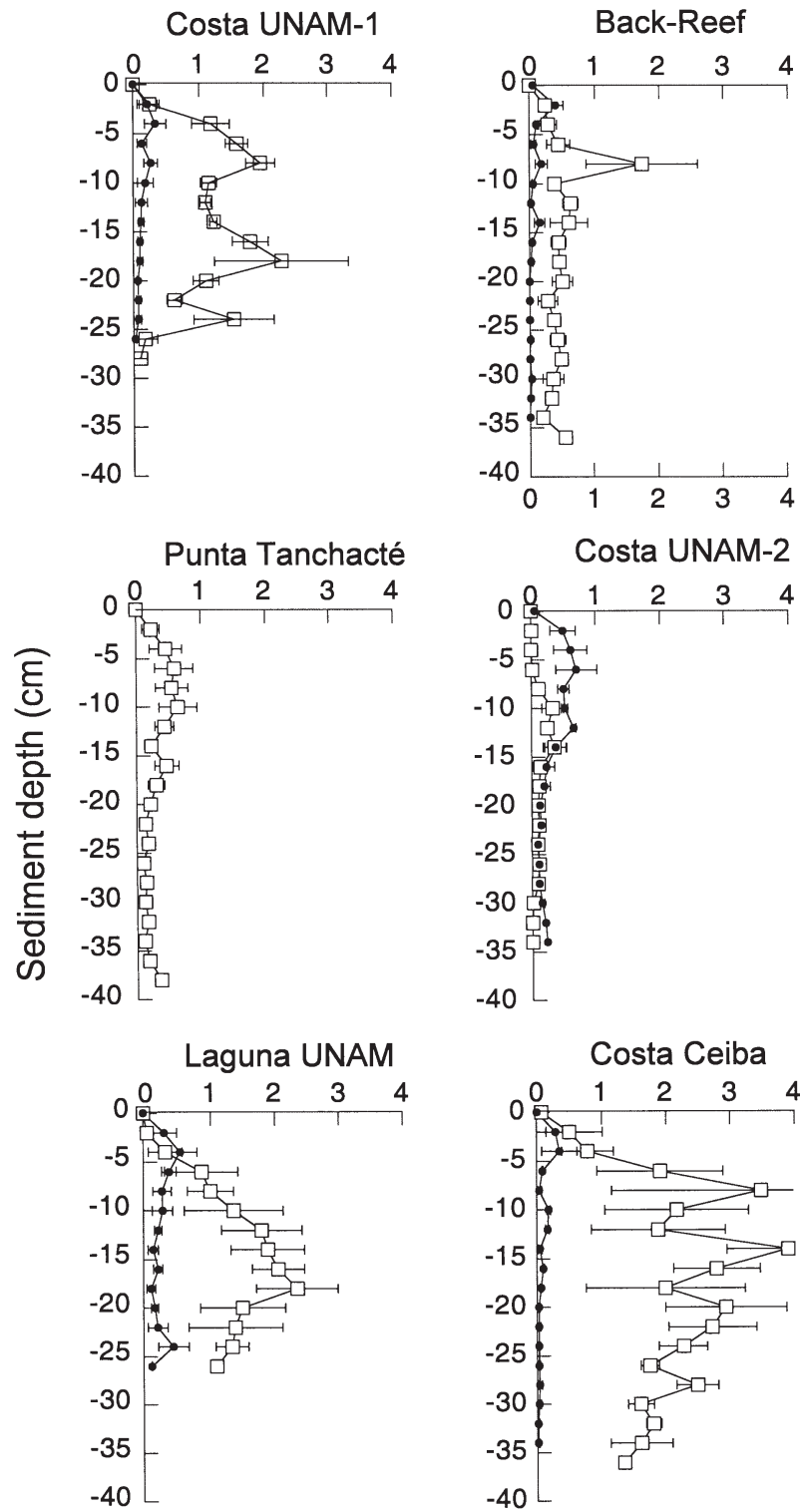

Root biomass (mg dw $\mathrm{cm}^{-3}$ )

Fig. 2. Depth profile of mean \pm SE root biomass $(n=4)$ of Thalassia testudinum (ㅁ) and Syringodium filiforme (•) within seagrass rhizosphere at 6 meadows at the Puerto Morelos reef lagoon 
Table 2. The sediment depth comprising 50 and $95 \%$ of the root biomass of Thalassia testudinum and Syringodium filiforme, community root biomass, and positive redox potential anomaly in the meadows studied; the mean ( \pm SE) value for all meadows is given

\begin{tabular}{|c|c|c|c|c|c|c|c|c|}
\hline \multirow[t]{2}{*}{ Centroidal depth site } & \multicolumn{2}{|c|}{$\begin{array}{c}\text { Thalassia } \\
\text { testudinum }(\mathrm{cm})\end{array}$} & \multicolumn{2}{|c|}{$\begin{array}{l}\text { Syringodium } \\
\text { filiforme }(\mathrm{cm})\end{array}$} & \multicolumn{2}{|c|}{$\begin{array}{l}\text { Seagrass } \\
\text { rhizosphere }(\mathrm{cm})\end{array}$} & \multicolumn{2}{|c|}{$\begin{array}{l}\text { Positive redox } \\
\text { potential anomaly }(\mathrm{cm})\end{array}$} \\
\hline & $50 \%$ & $90 \%$ & $50 \%$ & $90 \%$ & $50 \%$ & $90 \%$ & $50 \%$ & $90 \%$ \\
\hline Costa UNAM 1 & 10.1 & 43.7 & 6.8 & 29.7 & 9.7 & 42.1 & 10.6 & 45.9 \\
\hline Experimental site & 13.9 & 60.2 & 11.8 & 50.9 & 13.5 & 58.4 & & \\
\hline Arrecife & 12.8 & 55.4 & 5.0 & 21.6 & 11.7 & 50.7 & 14.2 & 61.5 \\
\hline Punta Tanchacté & 11.3 & 48.9 & & & 11.3 & 48.9 & 10.4 & 44.8 \\
\hline Costa UNAM 2 & 12.1 & 52.4 & 8.58 & 37.1 & 9.3 & 40.2 & & \\
\hline Laguna UNAM & 13.1 & 56.5 & 9.2 & 39.6 & 12.3 & 53.2 & 6.5 & 28.3 \\
\hline Ceiba orilla & 14.7 & 63.4 & 6.8 & 29.5 & 14.3 & 61.8 & & \\
\hline Mean & 12.6 & 54.4 & 8.0 & 34.8 & 11.7 & 50.8 & 10.4 & 45.1 \\
\hline SE & 0.6 & 2.5 & 0.9 & 3.8 & 0.7 & 3.0 & 1.1 & 4.8 \\
\hline
\end{tabular}

cies, with T. testudinum placing 50 and $95 \%$ of its root biomass within $12.6 \pm 0.58$ and $54.4 \pm 2.53 \mathrm{~cm}$ of the sediment surface, respectively, while $S$. filiforme placed 50 and $95 \%$ of its root biomass within $8.0 \pm 0.87$ and $34.7 \pm 3.8 \mathrm{~cm}$ of the sediment surface, respectively.

Negative redox potentials were encountered between 4 and $18 \mathrm{~cm}$ below the sediment surface (Fig. 3). There were important differences in the redox potential between vegetated and bare sediments, with surface sediments often having more positive redox potentials in bare sand than under plant canopies (Fig. 3). However, this tendency was reverted with increasing depth, such that the vegetated sediments maintained redox potentials above those of the adjacent bare sediments from depths greater than 10 to $16 \mathrm{~cm}$ (Fig. 3). The sediment layer with higher redox potentials in vegetated compared to adjacent bare sediments (i.e. positive anomaly) had a centroidal depth (i.e. the depth comprising $50 \%$ of the anomaly) ranging from 6 to $14 \mathrm{~cm}$ (Table 2), which was remarkably similar ( $t$-test, $\mathrm{p}>0.5$ ) to the centroidal depth of the seagrass roots in the sediments (Table 2). The centroidal depth of the positive redox anomaly in vegetated sediments was much closer to that of the root biomass of Thalassia testudinum, which comprised most (79\% on average) of the root biomass, compared to that of Syringodium filiforme (Table 2). The rhizosphere of the examined meadows presented maximum values of the positive anomaly ranging from 39 to $211 \mathrm{mV}$. The vertical coupling between sediment redox conditions and rhizosphere biomass suggests that seagrass roots modify the redox conditions of the colonised sediments.

Whether the positive redox anomaly found at depth in vegetated sediments derives from seagrass photosynthetic activity, was tested by shading vegetated plots to experimentally reduce seagrass photosynthetic activity. We found significant differences in the photo-

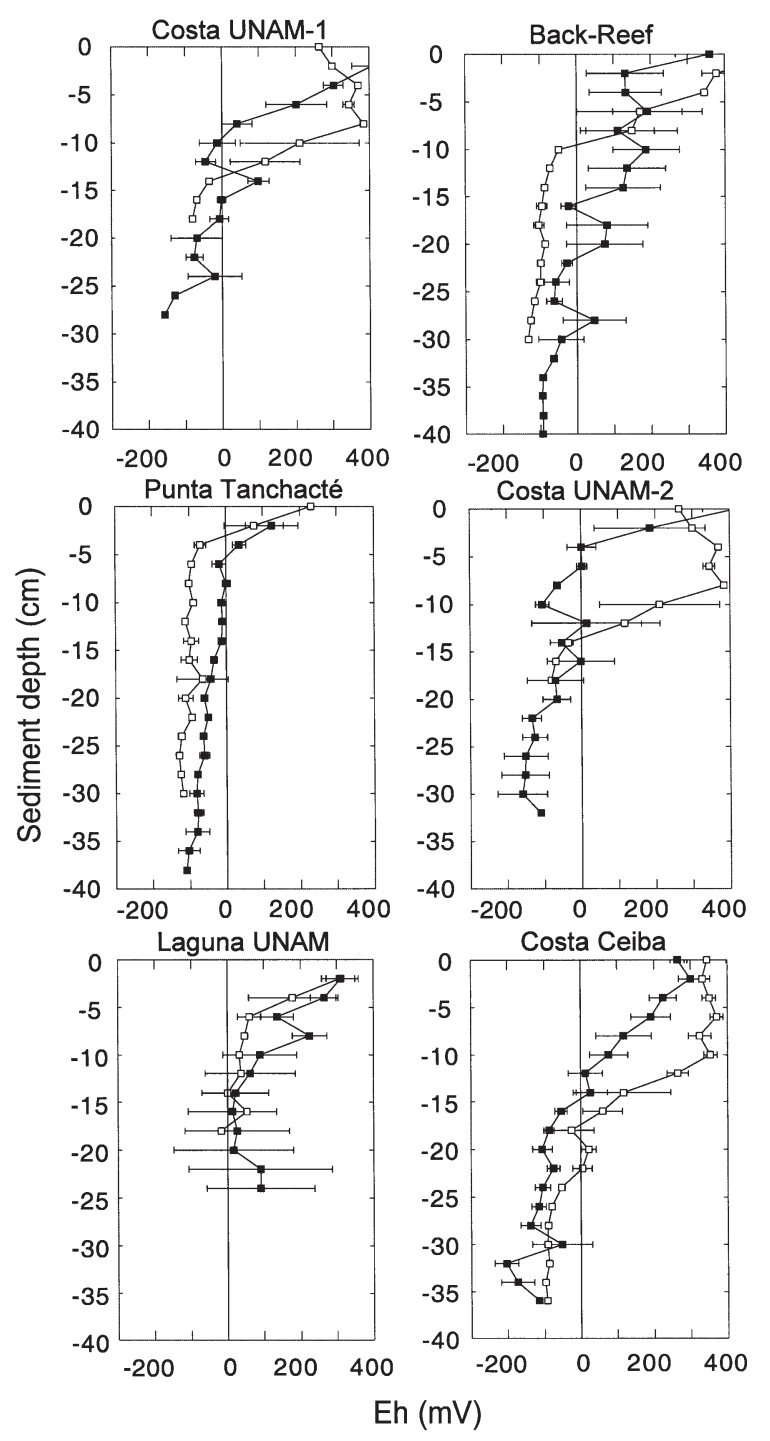

Fig. 3. Depth profiles of mean \pm SE redox potential in vegetated $(\square, n=4)$ and adjacent bare $(\square, n=3)$ sediments at 6 sites from Puerto Morelos reef lagoon 
synthetic rates, estimated as electron transport rates $(E T R)$, between control and shaded leaves ( $t$-test $\mathrm{p}<$ 0.01), and between initial (Day 2) and final (Day 10)
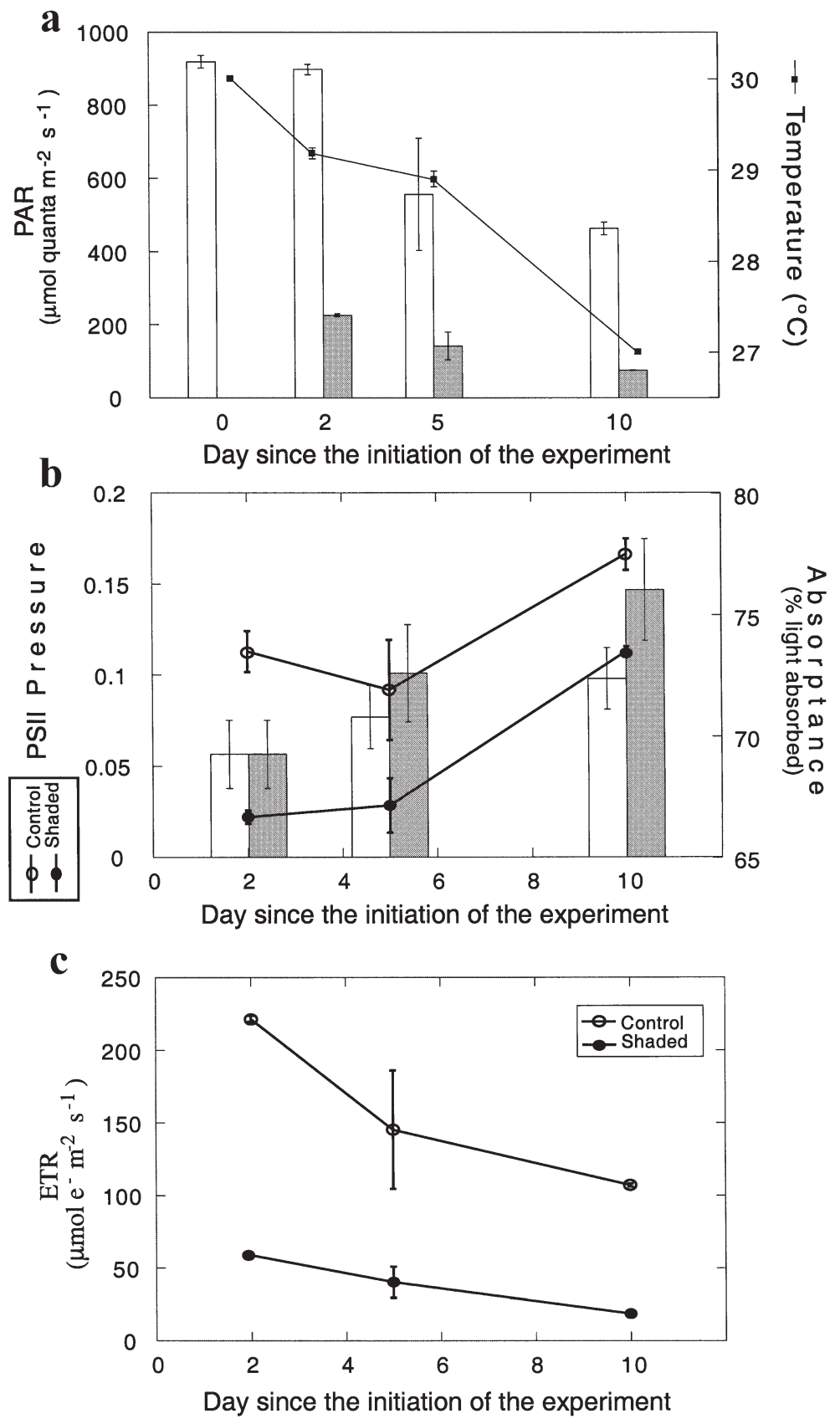

Fig. 4. (a) Mean \pm SE of PAR irradiance along the course of the experiment for control (open bars) and $73 \%$ shading treatment (filled bars), and mean \pm SE water temperature $\left({ }^{\circ} \mathrm{C}\right)$ during sampling (middle panel); (b) mean \pm SE of PSII pressure defined as [1 - (steady-state yield)/(maximum yield of dark adapted leaves)], and leaf absorptance (percentage of light absorbed by the leaf). O: PSII pressure of control treatment leaves, and $\bullet$ : PSII pressure of shaded leaves; open bars represent absorptance values of control leaves, and filled bars represent absorptance values of shaded leaves. (c) Mean \pm SE of Electron Transport Rate (ETR) throughout the experiment. O: control treatment and $\bullet$ : shading treatment values for both treatments ( $t$-test $\mathrm{p}<0.01$, Fig. $4 \mathrm{c}$ ). The differences in ETR of control and shaded Thalassia testudinum leaves closely matched those in the incident PAR (Fig. 4a,c), with the ETR of shaded $T$. testudinum leaves being about 4-fold lower on average than those of control plants, similar to the reduction in PAR imposed by shading (4.5-fold on average). The steadystate fluorescence yield $\left(F_{\mathrm{v}} / F_{\mathrm{m}}{ }^{\prime}\right)$ increased significantly ( $9 \%$ greater on average) in the shaded plants ( $t$-test, $\mathrm{p}<0.01), 2$ d after the onset of shading. These differences were observed along the experiment (Days 5 and 10) although a significant reduction (4 to $6 \%$ lower on average) was associated to a progressive decrease in $F_{\mathrm{v}} / F_{\mathrm{m}}$ ' for both treatments. The reduction observed in $F_{\mathrm{v}} / F_{\mathrm{m}}$ ' along the experiment was probably due to the stress caused by the passage of the frontal storm. To describe the effect of the experimentally induced reduction in light availability together with the effect of the frontal storm on leaf photosynthetic performance of $T$. testudinum, we used a descriptor of excitation pressure on PSII sensu Maxwell et al. (1995), estimated as $1-\left[\left(F_{\mathrm{v}} / F_{\mathrm{m}}{ }^{\prime}\right) / F_{\mathrm{v}} / F_{\mathrm{m}}\right]$, where $F_{\mathrm{v}} / F_{\mathrm{m}}$ is the maximum yield showed by dark-adapted leaves at the beginning of the experiment, and $F_{\mathrm{v}} / F_{\mathrm{m}}$ ' is the in situ steady-state yield measured at the peak of irradiance. According to the former definition, PSII excitation pressure varies between 0 (no pressure) and 1 (maximum pressure). The values estimated reflected lower PSII excitation pressure for the shaded leaves and a significant increase for both treatments at the end of the experiment (Fig. 4b). The maximum photochemical yield $\left(F_{\mathrm{v}} / F_{\mathrm{m}}\right)$ of dark-adapted leaves showed a similar $9 \%$ decrease for both control and shaded treatments $\left(F_{\mathrm{v}} / F_{\mathrm{m}}=0.73 \pm 0.007\right)$ at the end of the experiment (Day 10), confirming that T. testudinum photosynthetic performance was affected by the frontal storm. However, the values of the excitation pressure on PSII were all <0.2 (Fig. 4b), indicating low PSII pressure along the experiment on both treatments. In addition, light (PAR-average) absorption by the leaves (Absorptance) increased by $11 \%$ with increasing shading along the course of the experiment (initial = $69.27 \pm 1.4 \%, 10 \mathrm{~d}$ after shading: $76.2 \pm$ $1.2 \%$, Fig. 4 b), indicating a fast photoacclimation response of $T$. testudinum leaves 
over the short term of the experiment. Because the changes in $F_{\mathrm{v}} / F_{\mathrm{m}}$ ' and Absorptance were moderate (about 6 to $10 \%$ ) compared to the shading imposed (4.5-fold), the ETR variation was dominated by shading.

The passage of the frontal system caused stronger reductions in the photosynthetic rates than those induced by the experimental setup, due to the additional reduction in light availability and the effect of water temperature on plant photosynthetic performance. As a consequence, differences in sediment redox conditions between control and shaded plots were only significant for the first 5 d (Figs $5 \& 6$ ). The time series of redox conditions clearly showed a shift in the redox conditions of the shaded plots with time, involving a progressive reduction of the sediments (Fig. 5) to reach an average decline of the redox conditions by about $45 \mathrm{mV}$ by Day 5 (Fig. 6). A significant reduction of the sediments was already evident $2 \mathrm{~d}$ after shading was imposed at the depth where the positive redox anomaly associated to the presence of the plant was greatest (6 to $25 \mathrm{~cm}$, Wilcoxon sign ranked test, p < 0.01, Fig. 6). The anomaly extended throughout the entire sediment layer occupied by the plants ( 0 to $40 \mathrm{~cm}$, Wilcoxon sign ranked test, $\mathrm{p}<0.00055$ ) $5 \mathrm{~d}$ following the onset of shading (Fig. 6). The maximum negative anomaly at that time was found at the sediment surface and the deeper $(>35 \mathrm{~cm})$ layers.

\section{DISCUSSION}

The results presented show that seagrasses contribute to modify sediment redox conditions around their rhizosphere. This effect includes an increase in sediment redox potential around the rhizosphere, which most probably results from oxygen released by the roots (Pedersen et al. 1998, Connell et al. 1999, Terrados et al. 1999). This is supported by: (1) the observation of a similar distribution between the root biomass and the redox anomaly in the vegetated sediments; and (2) the direct evidence that a 3-fold reduction in the photosynthetic activity of the plants, due to shading, results in a reduction of the sediments. Oxygen release comprise a significant fraction of the photosynthetic oxygen evolved $(10 \%$ in Cymodocea rotundata Pedersen et al. 1998), as well as an apparent gradient-driven passive oxygen flow from the water to the sediment through the seagrass tissues (Pedersen et al. 1998).

Shading alone altered the photosynthetic activity of Thalassia testudinum, but the effect was not always proportional to the reduction of light intensity. In the first place, because the irradiance in the meadows was above the saturation irradiance $\left(I_{k}=300 \mu \mathrm{mol}\right.$ quanta $\mathrm{m}^{-2} \mathrm{~s}^{-1}$, Enríquez et al. 2000). Secondly, because the plants are capable of rapid photoacclimation (e.g. the average leaf elongation rate for the second youngest
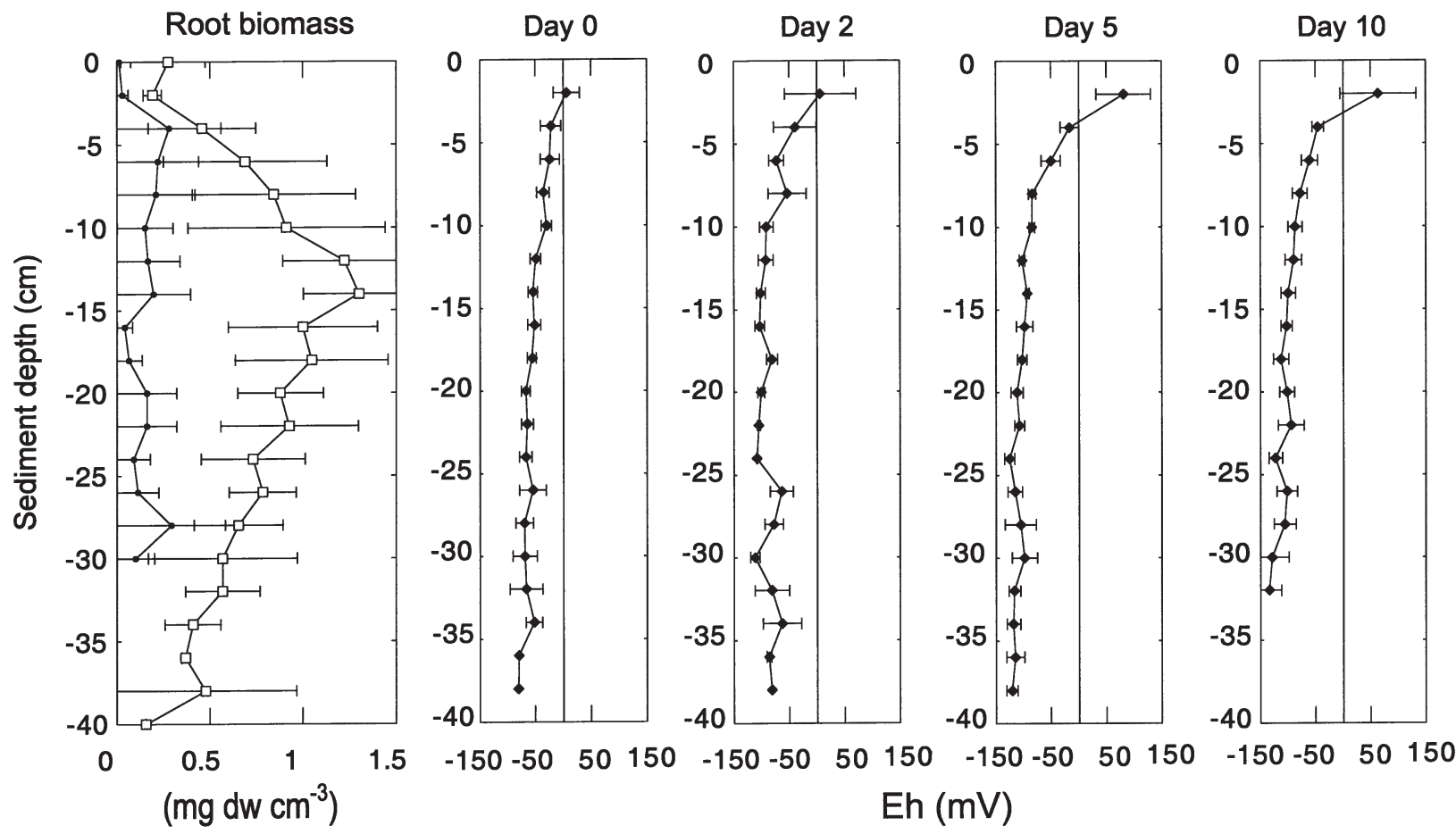

Fig. 5. Depth distribution of mean \pm SE root biomass of Thalassia testudinum $(\square, n=4)$ and Syringodium filiforme $(\bullet$, $n=4)$, and mean \pm SE redox potential at Days $0,2,5$, and $10(\mathrm{n}=3)$ after the initiation of the experiment within seagrass rhizosphere at the experimental site 

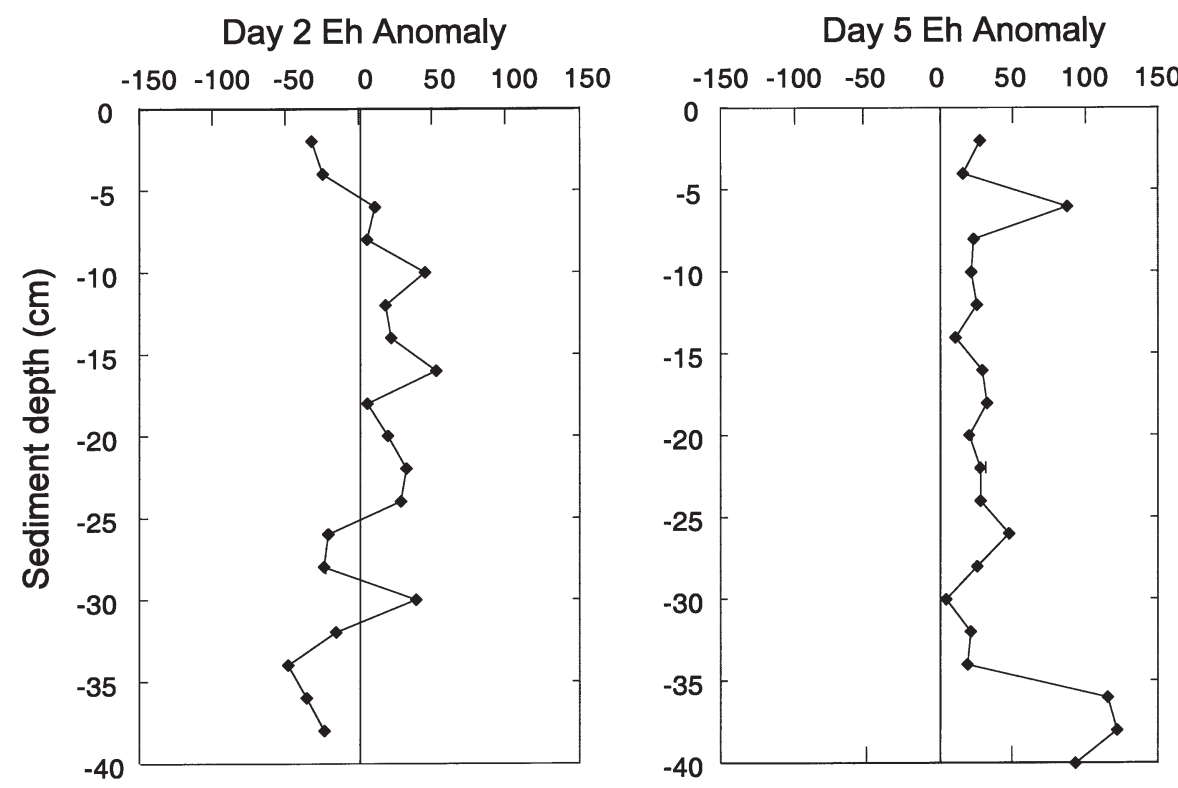

Fig. 6. Depth distribution of mean redox potential anomaly at Days 2 and 5 after the initiation of the experiment in the experimental site

creased organic inputs under the seagrass canopy (Pedersen et al. 1997); (2) a reduced activity of benthic microalgae in the surface sediments shaded by the seagrass canopy; or (3) greater instability of surface sediments from unvegetated areas (e.g. Terrados \& Duarte 1999). Resuspension of surface sediments should enhance the exchange of pore waters with the overlying oxygenated waters. Hence, sediment instability would lead to increased redox potential.

The time series of redox measurements following experimental shading clearly indicates these effects to be cumulative, and to propagate from the sediment layers containing the bulk of the rhizosphere $(10$ to $25 \mathrm{~cm})$ to the deeper layers (down to $40 \mathrm{~cm}$ below the surface) within a few days. Indeed,

leaf in the area, is close to $0.4 \mathrm{~cm} \mathrm{~d}^{-1}$, van Tussenbroek 1995). The leaves were indeed able to photoacclimate to the experimental shading as reflected in the significant increment in the light they absorbed. The differences observed in photosynthetic activity between treatments may also result from differences in the diel variation of the steady-state fluorescence yield. PAM measurements were recorded at the peak of irradiance, which generally coincide with the natural diel reduction in $F_{\mathrm{v}} / F_{\mathrm{m}}$ that has been extensively documented for algae, corals and seagrasses (i.e. Hanelt 1992, Hanelt et al. 1993, Franklin et al. 1996, Ralph et al. 1998, Enríquez unpubl. data). Control leaves showed significantly lower $F_{\mathrm{v}} / F_{\mathrm{m}}$ values than shaded leaves, but the differences were not sufficiently large (PSII pressure <0.2) to lead to photoinhibition, as we did not observe any significant reduction in ETR. The observed reduction in the photosynthetic activity between control and shaded plots was, therefore, mainly derived from differences in PAR irradiance resulting from the shading imposed. This difference resulted, on average, in a 4 -fold reduction in the photosynthetic activity of the T. testudinum leaves assayed in the shaded plots, which should lead to a reduced oxygen flow to the roots, accounting for the enhanced reducing sediment conditions in the shaded plots.

In addition to the effects of the seagrass rhizosphere on raising sediment redox, the upper layer (up to 0 to $10 \mathrm{~cm}$ in depth) of vegetated sediments tended to have more negative redox potential than bare sediments. This effect may be derived from: (1) a greater respiration in the upper sediment driven by the likely in- examination of the redox conditions in vegetated versus bare sediments shows that the redox anomaly has a similar depth distribution as that of the root biomass, with the centroidal depth of the anomaly being similar to that of the root biomass.

Root biomass was large in the meadows reaching up to $504 \mathrm{~g} \mathrm{DW} \mathrm{m}^{-2}$, and comprised a large fraction (14 to $46 \%$ ) of the total seagrass biomass, consistent with the nutrient limitation demonstrated for these meadows (Duarte et al. 1998). Seagrass roots form an extensive network within the sediments $\left(0.89 \mathrm{~m}^{2}\right.$ of roots $\mathrm{m}^{-2}$ for Thalassia testudinum in the Puerto Morelos reef lagoon, Duarte et al. 1998), and can therefore efficiently extend their effects throughout the sediment layer. Seagrass activity during the present study was able to attenuate sediment reduction by increasing sediment redox potential by about $69 \mathrm{mV}$ on average in the root layer. The increase of redox potential promoted by $T$. testudinum should modify the geochemistry of the sediments, as hypothesised by Hemminga (1998). In particular, the processes affected include: (1) stimulation of microbial activity associated to the rhizosphere (e.g. increase of sulphate reduction and nitrogen fixation, Welsh et al. 1997, Blaabjerg et al. 1998, McGlathery et al. 1998, Hansen et al. 2000); (2) prevention of the accumulation of toxic metabolites (e.g. sulphide, Terrados et al. 1999) in the rhizosphere; and (3) changes in nutrient ( $\mathrm{P}$ and $\mathrm{N}$ ) availability within in the rhizosphere (Reddy et al. 1989, Stumm \& Morgan 1996). However, the results presented here cannot, because of limitation of the Pt-electrode measurements used, provide direct insight into the effect of 
seagrass activity on sediment processes. Hence, future examination should combine measurements of seagrass activity with direct measurements of biogeochemical processes.

The examination of the effects of seagrasses on sediment conditions and the processes governing them is still in its infancy, particularly when compared to the knowledge already available on the metabolic interactions between seagrass leaves and the water column. However, seagrass-sediment interactions are important components of the functions of seagrasses in the ecosystem, and our results suggest, together with previous studies of root-sediment interactions (Kenworthy et al. 1982, Isaksen \& Finster 1996, Holmer \& Nielsen 1997, McGlathery et al. 1998), that seagrass play an important engineering (sensu Jones et al. 1997) role in controlling sediment biogeochemical conditions, thereby affecting the life of sediment infauna and key processes for the cycling of carbon and nutrients in these ecosystems.

Acknowledgements. This project was funded with an academic exchange grant from the Universidad Nacional Autónoma de Mexico (UNAM, Mexico) and the Consejo Superior de Investigaciones Científicas (CSIC, Spain). We thank Norma Isabel Pantoja Reyes for providing unpublished data on nitrate concentration in water and pore water in the area, and for help in the field and the laboratory. We are grateful to Daniel Gasca Flores for field and laboratory assistance, and to 2 anonymous reviewers for relevant comments.

\section{LITERATURE CITED}

American Public Health Association (1992) Standard methods for the examination of water and waste water, 18th edn. p 260-263

Blaabjerg V, Mouritsen KN, Finster K (1998) Diel cycles of sulphate reduction rates in sediments of a Zostera marina bed (Denmark). Mar Ecol Prog Ser 15:97-102

Connell EL, Colmer TD, Walker DI (1999) Radial oxygen loss from intact roots of Halophila ovalis as a function of distance behind the root tip and shoot illumination. Aquat Bot 63:219-228

Duarte CM, Cebrián J (1996) The fate of marine autotrophic production. Limnol Oceanogr 41:1758-1766

Duarte CM, Chiscano CL (1999) Seagrass biomass and production: a reassessment. Aquat Bot 65:159-174

Duarte CM, Merino M, Gallegos M (1995) Evidence of iron deficiency in seagrasses growing above carbonate sediments. Limnol Oceanogr 40:1153-1158

Duarte CM, Merino M, Agawin NSR, Uri J, Fortes MD, Gallegos ME, Marbà N, Hemminga MA (1998) Root production and belowground seagrass biomass. Mar Ecol Prog Ser 171:97-108

Franklin LA, Seaton GGR, Lovelock CE, Larkum AWD (1996) Photoinhibition of photosynthesis on a coral reef. Plant Cell Environ 19:825-836

Gale MR, Grigal DK (1987) Vertical root distributions of northern tree species in relation to successional status. Can J For Res 17:829-834

Gattuso JP, Frankignolle M, Wollast R (1998) Carbon and car- bonate metabolism in coastal aquatic ecosystems. Annu Rev Ecol Syst 29:405-434

Genty B, Briantais JM, Baker NR (1989) The relationship between the quantum yield of photosynthetic electron transport and quenching of chlorophyll fluorescence. Biochim Biophys Acta 990:87-92

Hanelt D (1992) Photoinhibition of photosynthesis in marine macrophytes of the South Chinese Sea. Mar Ecol Prog Ser 82:199-206

Hanelt D, Huppertz K, Nultsch W (1993) Daily course of photosynthesis in marine macrophytes investigated in the laboratory and in the field. Mar Ecol Prog Ser 97:31-41

Hansen JW, Udy JW, Perry CH, Dennison WC, Lomstein BA (2000) Effect of the seagrass Zostera capricorni on sediment microbial processes. Mar Ecol Prog Ser 199:83-96

Hemminga MA (1998) The root/rhizome system of seagrasses: an asset and a burden. J Sea Res 39:183-196

Holmer M, Nielsen SL (1997) Sediment sulfur dynamics related to biomass-density pattern in Zostera marina (eelgrass) beds. Mar Ecol Prog Ser 146:163-171

Isaksen MF, Finster K (1996) Sulphate reduction $\mathrm{n}$ the root zone of the seagrass Zostera noltii on the intertidal flats of a coastal lagoon (Arcachon, France). Mar Ecol Prog Ser 137:187-194

Jackson RB, Canadell J, EhleringerJR, Mooney HA, Sala OE, Schulze ED (1996) A global analysis of root distributions for terrestrial biomaes. Oecologia 108:389-411

Jones CG, Lawton JH, Shachak M (1997) Positive and negative effects of organisms as physical ecosystem engineers. Ecology 78:1946-1957

Kenworthy WJ, Zieman JC, Thayer GW (1982) Evidence for the influence of seagrasses on the benthic nitrogen cycle in a coastal plain estuary near Beaufort, North Carolina (USA). Oecologia 54:152-158

Maxwell DP, Falk S, Huner NPA (1995) Photosystem II excitation pressure and development of resistance to photoinhibition. Plant Physiol 107:687-694

McGlathery KJ, Risgaard-Petersen N, Christensen PB (1998) Temporal and spatial variation in nitrogen fixation activity in the eelgrass Zostera marina rhizosphere). Mar Ecol Prog Ser 168:245-258

Pedersen MF, Duarte CM, Cebrián J (1997) Rates of changes in organic matter and nutrient stocks during seagrass Cymodocea nodosa colonization and stand development. Mar Ecol Prog Ser 159:29-36

Pedersen O, Borum J, Duarte CM, Fortes MD (1998) Oxygen dynamics in the rhizosphere of Cymodocea rotundata. Mar Ecol Prog Ser 169:283-288

Ralph PJ, Gademann R, Dennison WC (1998) In situ seagrass photosynthesis measured using a submersible, pulseamplitude modulated fluorometer. Mar Biol 132:367-373

Reddy KR, Patrick WH Jr, Lindau CW (1989) Nitrificationdenitrification at the plant root-sediment interface in wetlands. Limnol Oceanogr 34:1004-1013

Schüring JS, Schulz HD, Fisher WR, Böttcher J, Duijnisveld WHM (2000) Redox. Fundamentals, processes and applications. Springer, Berlin

Shibbata K (1959) Spectrophotometry of translucence biological materials - opal glass transmission method. Meth Biochem Analysis 7:77-109

Stumm W, Morgan JJ (1996) Aquatic chemistry: chemical equilibria and rates in natural waters. Wiley-Interscience, New York

Terrados J, Duarte CM (1999) Experimental evidence of reduced particle resuspension within a seagrass (Posidonia oceanica L.) meadow. J Exp Mar Biol Ecol 243:45-53

Terrados J, Duarte CM, Kamp-Nielsen L, Borum J, Agawin 
NSR, Fortes MD, Gacia E, Lacap D, Lubanski M, Greve T (1999) Are seagrass growth and survival affected by reducing conditions in the sediment? Aquat Bot 65:175-197 van Tussenbroek BI (1995) Thalassia testudinum leaf dynamics in a Mexican Caribbean coral reef lagoon. Mar Biol 122:33-40

Editorial responsibility: Otto Kinne (Editor)

Oldendorf/Luhe, Germany
Welsh DT, Bourguès S, de Wit R, Auby I (1997) Effect of plant photosynthesis, carbon sources and ammonium availability on nitrogen fixation rates in the rhizosphere of Zostera noltii. Aquat Microb Ecol 12:285-290

Wilkinson L (1989) SYSTAT: the system for statistics. SYSTAT, Inc., Evanston

Submitted: June 5, 2000; Accepted: January 18, 2001

Proofs received from author(s): August 2, 2001 